\title{
Longitudinal study of circulating gastric antibodies in pernicious anaemia
}

\author{
R J L DAVIDSON, H I ATRAH, H F SEWELL* \\ From the Departments of Haematology and *Immunopathology, Aberdeen Royal Infirmary and University of \\ Aberdeen, Scotland
}

SUMMARY Temporal changes in gastric antibody response were investigated in 113 (51 men, 62 women) patients with confirmed pernicious anaemia. Their ages ranged from 31-92 years (mean (SD 13.2) 66). At diagnosis, parietal cell antibody and intrinsic factor antibody were detected in $90.9 \%$ and $39.1 \%$ of all patients, respectively. When the tests were repeated after a mean follow up of 70 months (range 14-137), parietal cell antibody and intrinsic factor antibody were positive in $82 \cdot 8 \%$ and $58.7 \%$, respectively. There was a definite but not significant trend for the organ specific parietal cell antibody to disappear; intrinsic factor antibody became more positive. These results may indicate that with progressive parietal cell destruction, the antigen is no longer available to sustain an immunological response. On the other hand, this hypothesis does not explain the increased prevalence of intrinsic factor antibody which is also a product of parietal cells.

The chronic atrophic gastritis associated with pernicious anaemia is generally thought to have an autoimmune basis, although the exact parts played by humoral and cellular immune components have not yet been clearly defined.' The hypothesis that mucosal damage is mediated by a humoral mechanism involving cytotoxic antibodies is strongly supported by the correlations established between lymphocyte subpopulations in the gastric mucosa and pernicious anaemia, and between lymphocyte subpopulations in the peripheral blood and the presence of intrinsic factor antibody. ${ }^{2-4}$

The disease is further characterised by the emergence of two types of gastric antibody detectable in serum as well as in gastric juice. Parietal cell antibody, which may contribute to mucosal destruction, is found in over $90 \%$ of patients with pernicious anaemia at diagnosis, but is also detectable in $15 \%$ of elderly people without evidence of pernicious anaemia. In contrast, intrinsic factor antibody, which is highly specific for pernicious anaemia, is detectable in only $40-70 \%$ of patients at clinical presentation, ${ }^{56}$ but its incidence seems largely to depend on the sensitivity of the laboratory technique used. ${ }^{78}$ Two types of circulating antibody to intrinsic factor have

Accepted for publication 25 May 1989 been recognised: blocking antibody (type I) andcô binding antibody (type II). Blocking antibody binds at? a site distal to the vitamin B12; binding antibody binds at a site distal to the vitamin B12-binding locus on intrinsic factor and the intrinsic factor- $\mathrm{B}_{12}$ complex, thereby preventing attachment of the intrinsic factor$B_{12}$ complex to the specific terminal ileal receptors. It has been reported that $20-50 \%$ of all intrinsic factor antibodies are pure type $I,{ }^{9-12}$ but recently a more sensitive method showed low concentration of type II antibody in all positive sera. ${ }^{12}$ The presence of type II antibody alone is rare. . $^{-12}$

The introduction of simple, specific, and effective treatment for pernicious anaemia in the form of parenterally administered hydroxocobalamin has largely removed the incentive to study its pathogenesis. Although the antibody response at clinical presentation has been extensively investigated, little, however, is yet known about the events which trigger the autoimmune process in pernicious anaemia, the role of parietal cell antibody, the interrelation and relative clinical importance of the two types of intrinsic factor antibody and their presence in either serum and gastric juice, or both. This study was primarily undertaken to establish the temporal pattern of gastric antibody response in pernicious anaemia which may in turn throw further light on the sequence of events in the immune response to the disease. 


\section{Patients and methods}

Patients with a definite diagnosis of pernicious anaemia were identified from the medical records of Aberdeen Royal Infirmary. Validation of the diagnosis of pernicious anaemia was based on all or a combination of the following criteria: a low serum B12 concentration; unequivocal megaloblastic bone marrow; serum intrinsic factor antibody; B12 malabsorption (Schilling or Dicopac test); satisfactory response to parenteral $\mathrm{B} 12$; and the absence of other recognisable causes of B12 deficiency. Clinical and laboratory details, including the duration of the disease and measurements of intrinsic factor antibody and parietal cell antibody at diagnosis were documented. The general practitioner of each patient was contacted and requested to send a clotted blood sample on which serum B12, intrinsic factor antibody, and parietal cell antibody tests were performed. Serum samples from 36 patients obtained at the time of diagnosis and stored at $-20^{\circ} \mathrm{C}$ for an average of three years were also available for retesting.

At diagnosis intrinsic factor antibody was identified by a competitive radioisotope technique, ${ }^{13}$ which was also used to test all new and original (stored) samples. For comparative and confirmatory purposes, all sera were subsequently tested for intrinsic factor antibody by a more sensitive radioassay (Diagnostic Products Corporation, Los Angeles, USA) after charcoal adsorption for two hours to remove free $B_{12}$ and its possible effect on the assay procedure. ${ }^{\prime}$ The kit detects type I intrinsic factor antibody; the method is based on the competitive inhibitory effect of the antibody on the radioactive vitamin $B_{12}\left({ }^{57} \mathrm{Co}-B_{12}\right)$ binding capacity of a solid phase intrinsic factor binder.

All sera (new and original) were tested for the presence of parietal cell antibody by an indirect immunofluorescence antibody technique using mouse stomach as substrate and a fluorescein conjugated anti-human globulin reagent. ${ }^{15}$

The $\chi^{2}$ test with one degree of freedom was used for statistical analysis.

\section{Results}

Serum was available from 51 men aged (mean (SD)) 67 (12) years) and 62 women (65 (14) years). The mean duration of disease was 70 months (range 14 137).

\section{CHANGES IN INTRINSIC FACTOR ANTIBODY}

Two sets of paired intrinsic factor antibody results (old and new samples) from 92 patients based on the aforementioned technique were available for comparison. At diagnosis $36(39 \cdot 1 \%)$ had originally been found to be positive; by contrast, $54(58.7 \%)$ of the new samples were positive $(0.01>p>0.001)$. Of the 36 original sera found to be positive, $25(69.4 \%)$ of the corresponding new samples remained positive. Similarly, of the 56 original sera found to be negative, $29(51.8 \%)$ had become positive.

Thirty four samples stored from the time of diagnosis were available for intrinsic factor antibody retesting by the technique. Retesting showed that six were positive and 28 negative; six sera previously positive now yielded a negative result, probably signifying deterioration and loss of antibody activity on storage. One negative serum was found to give a positive result, probably indicating previous false negativity.

Intrinsic factor antibody response was further determined by testing 87 of the 92 new serum samples by the more sensitive kit method: $60(69 \%)$ were found to be positive. Seventeen samples reported as negative by the technique were found to be positive by the kit. On the other hand, the kit failed to detect positivity in seven samples positive by the technique. The kit was also used to test 31 of the 36 stored samples: positivity was recorded in $20(64.5 \%)$ compared with seven $(22 \cdot 6 \%)$ by the technique.

\section{CHANGES IN PARIETAL CELL ANTIBODY}

Two complete sets of parietal cell antibody results based on the one technique from 99 patients were available for comparison. Positive results were obtained in $90(90.9 \%)$ at diagnosis but in only 82 $(82.8 \%)$ of the new samples. The difference was not significant $(0 \cdot 10>p>0.05)$. Of the 90 original sera found to be positive, $78(86.7 \%)$ of the corresponding new samples still gave a positive result. Similarly, of the nine original sera found to be negative, four $(44.4 \%)$ had become positive.

Thirty six samples stored from the time of diagnosis were also retested for parietal cell antibody by the original technique. The results were identical with those originally recorded (34 positive and two negative), but two had become negative and two negative sera had become positive.

At diagnosis no patient was found to have a negative parietal cell antibody and a positive intrinsic factor antibody pattern. Surprisingly, seven such patients were, however, identified on testing the new samples, all having a positive intrinsic factor antibody by both techniques. At diagnosis parietal cell antibody was positive in all seven; intrinsic factor antibody was negative in four, positive in one, and the result could not be traced in two. The interval between the two tests ranged from two to 10 years (average $4 \cdot 3$ years).

The association of intrinsic factor antibody and parietal cell antibody at diagnosis with age and sex and that between the antibody response of new samples, and the duration of the disease are summarised in the table. 
Table Intrinsic factor antibody and parietal cell antibody related to age, sex, and duration of disease

\begin{tabular}{|c|c|c|c|}
\hline & $\begin{array}{l}\text { No of patients } \\
\text { tested }\end{array}$ & $\begin{array}{l}\text { Positive } \\
\text { results }\end{array}$ & $\begin{array}{l}\text { Percentage } \\
\text { positive }\end{array}$ \\
\hline \multicolumn{4}{|c|}{ Intrinsic factor antibody at diagnosis related to age } \\
\hline $\begin{array}{l}\leq 50 \text { years } \\
>50 \text { years }\end{array}$ & $\begin{array}{l}16 \\
78\end{array}$ & $\begin{array}{r}6 \\
30\end{array}$ & $\begin{array}{l}37 \cdot 5 \\
38 \cdot 5\end{array}$ \\
\hline \multicolumn{4}{|c|}{ Parietal cell antibody at diagnosis related to age } \\
\hline $\begin{array}{l}\leq 50 \text { years } \\
>50 \text { years }\end{array}$ & $\begin{array}{l}17 \\
82\end{array}$ & $\begin{array}{l}16 \\
74\end{array}$ & $\begin{array}{l}94 \cdot 1 \\
90 \cdot 2\end{array}$ \\
\hline \multicolumn{4}{|c|}{ Intrinsic factor antibody at diagnosis related to sex } \\
\hline$(0.50>p>0.10){ }_{F}^{M}$ & $\begin{array}{l}42 \\
52\end{array}$ & $\begin{array}{l}13 \\
23\end{array}$ & $\begin{array}{l}31 \\
44 \cdot 2\end{array}$ \\
\hline \multicolumn{4}{|c|}{ Parietal cell antibody at diagnosis related to sex } \\
\hline$(0.05>p>0.02) \quad \underset{F}{M}$ & $\begin{array}{l}44 \\
55\end{array}$ & $\begin{array}{l}37 \\
53\end{array}$ & $\begin{array}{l}84 \\
96 \cdot 4\end{array}$ \\
\hline \multicolumn{4}{|c|}{$\begin{array}{l}\text { Intrinsic factor antibody (new samples by the original technique) } \\
\text { related to duration of disease }\end{array}$} \\
\hline $\begin{aligned}(0.05>p>0.02) & <5 \text { years } \\
& \geq 5 \text { years }\end{aligned}$ & $\begin{array}{l}46 \\
52\end{array}$ & $\begin{array}{l}21 \\
34\end{array}$ & $\begin{array}{l}45 \cdot 7 \\
65 \cdot 4\end{array}$ \\
\hline \multicolumn{4}{|c|}{ Parietal cell antibody (new samples) related to duration of disease } \\
\hline $\begin{aligned}(0.05>p>0.02) & <5 \text { years } \\
& \geq 5 \text { years }\end{aligned}$ & $\begin{array}{l}47 \\
52\end{array}$ & $\begin{array}{l}40 \\
44\end{array}$ & $\begin{array}{l}85 \cdot 1 \\
84 \cdot 6\end{array}$ \\
\hline
\end{tabular}

\section{Discussion}

Numerous studies of gastric antibodies in pernicious anaemia, atrophic gastritis, and other immune disorders have been published. ${ }^{56}$ They have provided ample data on the prevalence of parietal cell antibody and intrinsic factor antibody in pernicious anaemia at diagnosis, in atrophic gastritis, and thyroid disease and have established the association between the latter two groups of disorders and pernicious anaemia. Of the few longitudinal studies published, one failed to show progression to pernicious anaemia in several patients with thyroid disease, atrophic gastritis, and serum intrinsic factor antibody who were followed up for three to seven years. ${ }^{16} \mathrm{~A}$ more recent study, although tentatively supporting the development of pernicious anaemia in patients with hypothyroidism, emphasised that no longitudinal study has recorded the initial intrinsic factor antibody seroconversion and that frank pernicious anaemia may, on average, take as long as 11 years to develop. ${ }^{17}$

In patients with pernicious anaemia, Ungar et al reported that with increasing duration of the disease, the incidence of intrinsic factor antibody increased while that of parietal cell antibody remained constant. ${ }^{18}$ They predicted that all patients with pernicious anaemia would eventually develop detectable circulating intrinsic factor antibody. Shortly after, in a similar study, Samloff et al concluded that the incidence of gastric antibodies was not significantly related to sex, duration of the disease, or age at diagnosis but documented that blocking antibody increased, albeit not significantly, both with increasing duration of disease and with decreasing age at diagnosis. ${ }^{19}$ These authors also confirmed that there was no relation between parietal cell antibody and intrinsic factor antibody, either of the blocking or the binding type. The shortage of information and lack of agreement regarding the changes in the pattern of gastric antibodies in pernicious anaemia with time is perhaps not surprising because once pernicious anaemia is diagnosed and treated regularly with parenteral $\mathbf{B}_{12}$, there is no clinical indication to reinvestigate the antibody response of patients. Furthermore, in patients so treated, the very high and unphysiological serum $B_{12}$ concentrations attained may interfere with tests for intrinsic factor antibody and give rise to false positive results. ${ }^{20}$ To overcome this difficulty serum $B_{12}$ concentrations of the test samples can be reduced by repeated dialysis or more effectively by charcoal adsorption. Some of the recently introduced methods, including commercially available kits, for detecting intrinsic factor antibody are not affected unless the serum $B_{12}$ concentration exceeds $3500 \mathrm{ng} / \mathrm{l}^{21}$ According to the manufacturer, the kit used in our study is free from any $B_{12}$ effect up to concentrations of $30000 \mathrm{ng} / \mathrm{l}$.

The sensitivity of some of the new kit techniques for detection of intrinsic factor antibody and consequently the percentage of the positive samples detected is said to be higher than that of the older methods. ${ }^{7}$ These claims are confirmed by the results obtained not only in this study but also by further observations (unpublished) made in our laboratory. Thus of 100 routine samples found to have subnormal serum $B_{12}$ concentrations $(<170 \mathrm{ng} / \mathrm{l})$, intrinsic factor antibody was detected in 17 by the kit compared with only three by the technique. In our experience with the two methods, however, we noted that positivity is not necessarily concurrent.

To ensure comparability of our results the antibody response of the stored samples was assessed by the 
same techniques used at diagnosis and results similar to those originally recorded were obtained. Thus any difference in antibody response between the original and recent samples is likely to have been genuine and not attributable to methodological changes, including test sensitivity.

We conclude from this study that as pernicious anaemia progresses, parietal cell antibody tends to disappear and intrinsic factor antibody tends to increase. The behaviour of parietal cell antibody, an organ specific antibody, seems to be analogous to that described in relation to thyroid microsomal antibody in some thyroid disorders. ${ }^{22}$ The disappearance of parietal cell antibody may be related to the gradual and eventual loss of antigenic stimulation from progressive parietal cell destruction-a burning out of the autoimmune process. In pernicious anaemia there is a decline in total output of intrinsic factor which is either absent or present in small concentrations in the gastric juice. ${ }^{23}$ This paradoxical persistence and even the increased prevalence of intrinsic factor antibody elude satisfactory explanation but are analogous to that of thyroglobulin antibody which may remain positive after the loss of thyroid microsomal antibody, although in some patients both of these antibodies may be lost eventually. ${ }^{22}$ It is conceivable that until failure of intrinsic factor secretion stops completely, intrinsic factor may gain entry to the submucosa or to the circulation via the damaged mucosa where it may stimulate the formation of parietal cell antibody.

We thank Mrs Norma Cruickshank and Mr P Drew for their expert technical assistance and Mrs Irene Watson for typing the manuscript.

\section{References}

1 Chanarin I. The megaloblastic anaemias. Oxford: Blackwell Scientific Publications, 1979:351-77.

2 Kaye MD, Whorwell PJ, Wright R. Gastric mucosal lymphocyte subpopulations in pernicious anaemia. Clin Immunol Immunopathol 1983;28:431-40.

3 Wodzinski MA, Forrest MJ, Barnett D, Lawrence ACK. Lymphocyte subpopulations in patients with hydroxycobalamin responsive megaloblastic anaemia. J Clin Pathol 1985;38:582-4.

4 Gogos CA, Kapatais-Zoumbos KN, Zoumbos NC. Lymphocyte subpopulations in megaloblastic anaemia due to vitamin B-12 deficiency. Scand J Haematol 1986;37:316-8.

5 Hoffbrand AV. Vitamin B12 and folate metabolism: The megaloblastic anaemias and other nutritional anaemias. In:
Hardistry RM, Weatherall DV, eds. Blood and its disorders. Oxford: Blackwell Scientific Publications, 1982:199-263.

6 Wintrobe MM, Lee GR, Boggs DR, et al. Clinical Haematology. Philadelphia: Lea and Febiger, 1981:566.

7 Dawson DW, Fish DI, Frew IDO, Troome T, Tilston I. Laboratory diagnosis of megaloblastic anaemia: current methods assessed by external quality assurance trials. $J$ Clin Pathol 1987;40:393-7.

8 Shackleton PJ, Fish DI, Dawson DW. Intrinsic factor antibody tests. J Clin Pathol 1989;42:210-2.

9 Garrido-Pinson GC, Turner MD, Crookston JH, et al. Studies of human intrinsic factor autoantibodies. J Immunol 1966;97: 897-912.

10 Schade SG, Abels J, Schilling RF, et al. Studies on antibody to intrinsic factor. $J$ Clin Invest 1967;46:615-20.

11 Rothenberg SP, Kanagi Kantha KR, Ficarra A. Antibodies to intrinsic factor: their determination and clinical usefulness. $J$ Lab Clin Med 1971;77:476-84.

12 Conn DA. Detection of Type I and Type II antibodies to intrinsic factor. Med Lab Sci 1986;43:148-51.

13 Reeves WG, Marriott DW. Radioisotope techniques. In: Thompson RA, ed. Techniques in clinical immunology. Oxford: Blackwell Scientific Publications, 1981:149-55.

14 Shum HY, O'Neill BJ, Streeter AM. A modified method for assaying intrinsic factor blocking antibody in serum. Pathology 1971;3:311-5.

15 Johnson GD, Dorling J. Immunofluorescence and immunoperoxidase techniques. In: Thompson RA, ed. Techniques in clinical immunology. Oxford: Blackwell Scientifc Publications, 1981:106-37.

16 Rose MS, Chanarin I, Doniach D, Brostoff J, Ardeman S. Intrinsic factor antibodies in absence of pernicious anaemia: $3-7$ year follow-up. Lancet 1970;ii:9-12.

17 Conn DA. Intrinsic factor antibodies in relation to disease. Med Lab Sci 1986;43:220-4.

18 Ungar B, Whittingham S, Francis CM. Pernicious anaemia: incidence and significance of circulating antibodies to intrinsic factor and to parietal cells. Aust Ann Med 1967;16:226-9.

19 Samloff M, Kleiman MS, Turner MD, Sobel MV, Jeffries GH. Blocking and binding antibodies to intrinsic factor and parietal cell antibody in pernicious anaemia. Gastroenerology 1968;55:575-83.

20 Gottlieb C, Lau KS, Wasserman LR, Herbert V. Rapid charcoal assay for intrinsic factor (IF), gastric juice unsaturated B12 binding capacity, antibody to IF, and serum unsaturated B12 binding capacity. Blood 1965;25:875-84.

21 Muckerheide MM, Wolfman JA, Rohde DA, McManamy GE. Studies on a radioassay for intrinsic factor antibody: Comparison of methods and false positive results due to elevated serum B12 levels. Am J Clin Pathol 1984;82:300-4.

22 Doniach D, Bottazzo GF, Drexhage HA. The autoimmune endocrinopathies. In: Lachman PJ, Peters DK, eds. Clinical aspects of immunology. Oxford: Blackwell Scientific Publications, 1982:903-37.

23 Chanarin I. The megaloblastic anaemias. Oxford: Blackwell Scientific Publications, 1979:354.

Requests for reprints to: Dr R J L Davidson, Haematology Department, Aberdeen Royal Infirmary, Foresterhill, Aberdeen AB9 2ZB, Scotland. 